\title{
Evaluation of Corpus Luteum Vascularization in Recipient Mares by Using Color Doppler Ultrasound
}

\author{
Marlon de Vasconcelos Azevedo', Natália Matos Souza' ${ }^{2}$, Felipe Augusto Boudoux Martins Sales' \\ José Carlos Ferreira-Silva', Maiana Silva Chaves ${ }^{3}$, Joane Isis Travassos Vieira', \\ José Pompeu Santos Filho' \& Marcos Antonio Lemos de Oliveira'
}

\begin{abstract}
Background: Embryo transfer is one of the most commonly used reproductive biotechnique. The success of embryo transfer is also affected by the synchrony of estrus and ovulation between donor and recipient animals. In horse reproduction, ultrasonography has been used, among other purposes, to diagnose early pregnancy. However, only the color Doppler imaging mode makes it possible to evaluate the vascular architecture and the hemodynamic aspects of the vessels in several organs, especially the corpus luteum. The objective of this study was to evaluate, based on the color Doppler ultrasound, the corpus luteum vascularization and function from recipient mares at embryo transfer timing.

Materials, Methods \& Results: Mangalarga Machador mares from 5 to 10-year-old and a range of live weights of between 350 to $450 \mathrm{~kg}$ were used for this experiment, kept in pasture-based on mombaça grass (Panicum maximum) and were given ad libitum access to water and mineral supplementation. The animals $(\mathrm{n}=15)$ were gynecologically examined and uterine consistency was evaluated by rectal palpation the same operator using an ultrasound system (SonoScape ${ }^{\circledR}$ ) with a linear transducer, and operating frequency ranging from 5 to $10 \mathrm{Mhz}$. The uterine tone was classified between grades 1 and 4 and subjected to ovulation induction. The objective and subjective vascular perfusion of the corpus luteum was evaluated by color Doppler ultrasound on the day of embryo transfer and endometrium. The determination progesterone concentration on the day of the embryo transfer was performed by direct chemiluminescence assay. The arcsine $(\sqrt{ } \mathrm{P} / 100)$ transformation was applied to the percentage data, and the results were expressed as mean (.) \pm standard error of the mean (SEM). Further, the assumptions of normality and homoscedasticity were verified, respectively, based on the Shapiro-Wilk and Lilliefors tests. Regarding the parametric and non-parametric variables, were applied, respectively, analysis of variance (ANOVA) followed by Tukey's test, and the Kruskal-Wallis test followed by Dunn's test. Pearson's correlation coefficient was used to evaluate the relationship between the parameters. The statistical program SPSS 16.0 was used to perform the over-mentioned analyses, and a p-value $<0.05$ was taken as significant. Corpus luteum vascular perfusion, based on the objective and subjective evaluation methods, and the progesterone concentration were higher in the pregnant mares $(P<$ $0.05)$. The objective and subjective methods for evaluation of the vascular perfusion in the corpus luteum were positively correlated between themselves as well as to progesterone concentration $(P<0.05)$. There was no significant difference between the groups considering the uterine tonus evaluation $(P>0.05)$.

Discussion: Mares that later became pregnant showed a higher concentration of progesterone as an outcome of the higher vascularization in the corpus luteum. It can be supported by both the correlation between the progesterone concentration and the corpus luteum vascular perfusion, as well as by the higher values of the vascular perfusion in pregnant mares. Based on the results, it has been concluded that the color Doppler ultrasound evaluation is an accurate tool to determine the corpus luteum vascularization, whether considering the objective or subjective methods. Also, the vascular perfusion is the most efficient parameter to determine both the corpus luteum function and to predict the ability of the recipient mares to maintain pregnancy.
\end{abstract}

Keywords: deslorelin acetate, ovary, reproduction.

DOI: $10.22456 / 1679-9216.110960$

${ }^{1}$ Departamento de Reprodução Animal, Universidade Federal Rural de Pernambuco (UFRPE), Recife, PE, Brazil. ${ }^{2}$ Departamento de Medicina Veterinária, Universidade Federal de Campina Grande (UFCG), PB, Brazil. ${ }^{3}$ Departamento de Medicina Veterinária, Universidade Estadual do Ceará (UECE), Fortaleza, CE, Brazil. CORRESPONDENCE: M.A.L. Oliveira [maloufrpe@gmail.com]. Departamento de Reprodução Animal - UFRPE. Rua Dom Manuel de Medeiros s/n. CEP 52171-900 Recife, PE, Brazil. 


\section{INTRODUCTION}

Embryo transfer is a reproductive biotechnology that provides better usage of animals with high genetic merit. The success of embryo transfer is also affected by the synchrony of estrus and ovulation between donor and recipient animals $[9,14]$. This synchrony can be affected, among other factors, by the duration of luteal phase in the recipient mares $[13,17]$. The corpus luteum is a transient endocrine gland, and its role is to produce progesterone (P4), which is needed to maintain the gestation $[10,19]$.

The color Doppler imaging mode makes it possible to evaluate the vascular architecture and the hemodynamic aspects of the vessels in several organs, especially the corpus luteum $[8,12]$. Generally, the vascularization and function of the corpus luteum are important features to be considered when selecting recipient mares to embryo transfer [19,11]. Furthermore, promising synchronization results have been achieved when the ovarian stimulation is performed by using deslorelin acetate at low doses [3,18]. However, few studies have been evaluated the corpus luteum features at the embryo transfer timing in recipient mares submitted to induction of ovulation with deslorelin acetate.

Based on the above considerations, it was hypothesized that the vascularization and function of the corpus luteum, at the embryo transfer timing, would be higher in mares detected later as pregnant. Thereby, this study aimed to evaluate the corpus luteum vascularization and function, at embryo transfer timing, based on the objective and subjective evaluation approaches by using the color Doppler ultrasound, in recipient mares subjected to induction of ovulation with deslorelin acetate.

\section{MATERIALS AND METHODS}

\section{Experimental animals and place}

The experimental trial was performed during the breeding season in "Central de Reprodução Equestre", Itabaiana-PB, Brazil, geographically located at latitude $7^{\circ} 19^{\prime} 44$ “south and longitude $35^{\circ} 19^{\prime} 58^{\prime}$ " west.

Mangalarga Machador mares from 5 to 10 -yearold and a range of live weights of between 350 to $450 \mathrm{~kg}$ were used for this experiment. The animals were gynecologically examined, kept in pasture-based on mombaça grass (Panicum maximum) and were given ad libitum access to water and mineral supplementation $\left(\operatorname{Kromium}^{\circledR}\right)^{1}$.

\section{Synchronization of the recipient mares}

The recipient mares were treated with $7.5 \mathrm{mg}$ of dinoprost-tromethamine $\left(\text { Lutalyse }^{\circledR}\right)^{2}$, via intramuscular
(IM). Then, the ovaries were examined daily by using Bmode ultrasonography until the largest follicle reached the diameter of $33 \mathrm{~mm}$ and the endometrium showed edema between grades 2 or 3 , as suggested by Curran $\&$ Ginther [6]. At that time, the ovulation was induced with $1500 \mu \mathrm{g}$ of deslorelin acetate $\left(\text { Sincrorelin }^{\circledR}\right)^{3}$ via IM. Ultrasound examinations were carried out on daily-basis through B-mode until ovulation was detected.

\section{Uterus and corpus luteum evaluation}

The uterine consistency was evaluated by rectal palpation, and the uterine tone was classified between grades 1 and 4, as proposed by Oliveira Neto et al. [20].

Transrectal ultrasound examinations were carried out by the same operator using an ultrasound system $\left(\text { SonoScape }{ }^{\circledR}\right)^{4}$ with a linear transducer, and operating frequency ranging from 5 to $10 \mathrm{Mhz}\left(\text { SonoScape }^{\circledR}\right)^{4}$. The corpus luteum was evaluated by color Doppler ultrasound on the day of embryo transfer. The area $\left(\mathrm{mm}^{2}\right)$ and the diameter $(\mathrm{mm})$ of the corpus luteum were measured from a B-mode image, as determined by Curran \& Ginther [6].

The subjective evaluation of the corpus luteum vascular perfusion was performed based on a film with a minimum duration of $60 \mathrm{~s}$, which was used to determine the percentage of luteal tissue with colored signals. The result of the subjective evaluation was estimated by the percentage of colored pixels observed in the image, as suggested by Ginther et al. [11] and shown in Figure 1 . The subjective evaluation of the endometrium vascular perfusion was scored from 1 to 4 [11].

Regarding the objective evaluation, the vascular perfusion of the corpus luteum and endometrium were estimated by using three images that showed a higher amount of colored signals in the luteal area based on the Adobe PhotoShop 5.5 program (Adobe Systems) ${ }^{5}$. The total number of pixels and the intensity were generated by the ImageJ $1.31 \mathrm{v}$ program (National Institutes of Health, Bethesda, MD). The number of colored pixels was transformed into vascularized luteal area considering one color pixel as $0.0465 \mathrm{~mm}^{2}$ of the area.

\section{Hormonal analysis}

On the day of embryo transfer, jugular vein blood collection was carried out using a $4 \mathrm{~mL}$ (Vacuette $\left.{ }^{\circledR}\right)^{6}$ tube coated with a clot activator $\left(\mathrm{SiO}_{2}\right)$ and a $25 \times 8$ needle. The determination of the progesterone concentration was performed by direct chemiluminescence assay $\left(\text { Immulite } \mathrm{I}^{\circledR}\right)^{7}$. The analytical sensitivity was 0.2 $\mathrm{ng} / \mathrm{mL}$, and accuracy 106 intra-assays ranged from 6.3 to $16 \%$, and inter-assay from 5.8 to $16 \%$. 


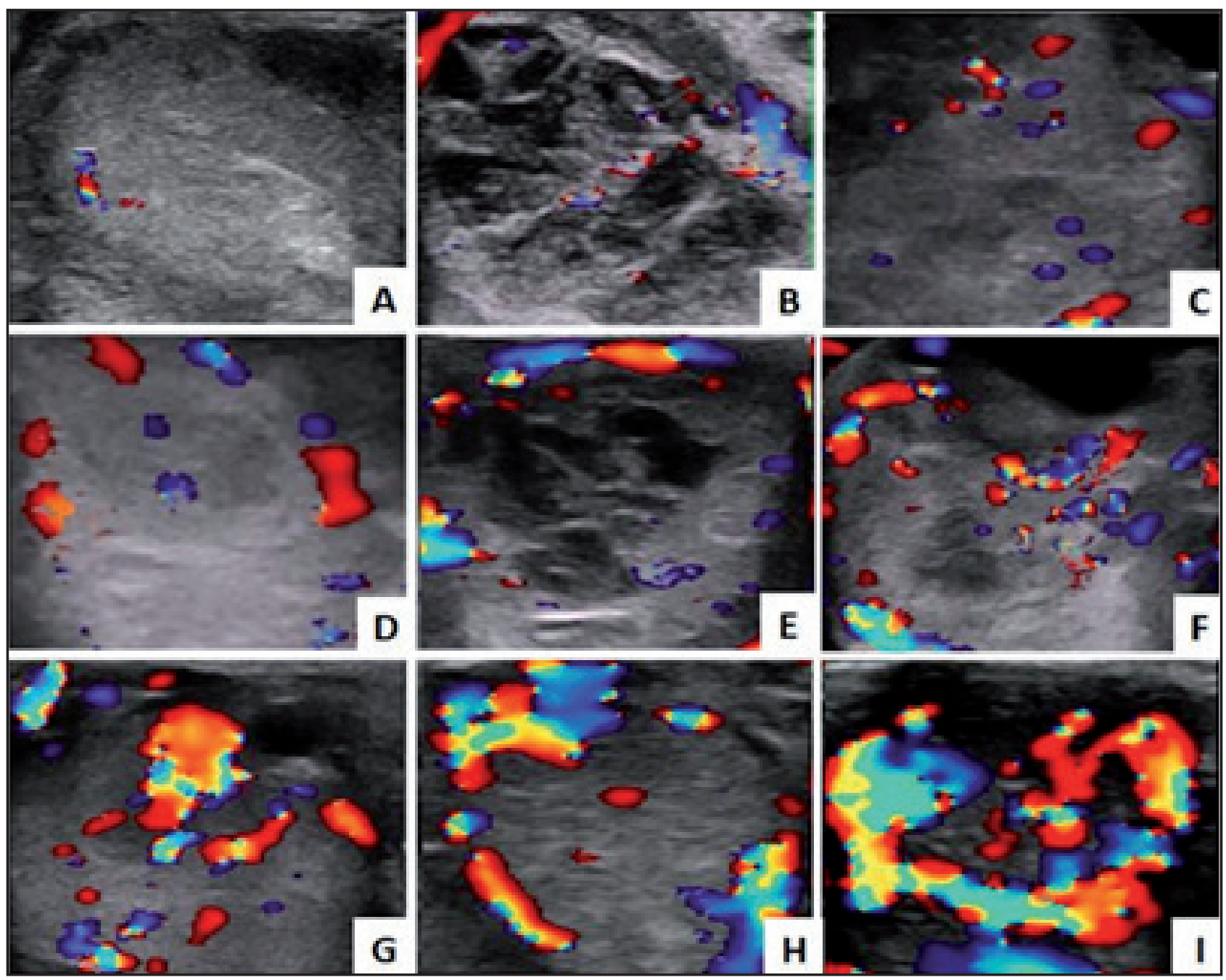

Figure 1. Representative images based on the subjective evaluation of the corpus luteum vascular perfusion on the day of ovulation from recipient mares stimulated at embryo transfer timing. Percentage of the endometrium vascularization: $5 \%$ (A), $10 \%$ (B), $20 \%$ (C), 30\% (D), 50\% (E), 60\% (F), $70 \%$ (G), $80 \%(\mathrm{H})$, and $90 \%(\mathrm{I})$.

Embryo transfer and pregnancy diagnosis

Blastocyst embryos (D7) were transferred to the recipient mares on the sixth day after ovulation, as suggested by Ferreira-Silva et al. [9]. Uterus, corpus luteum, and progesterone levels were evaluated when the embryo was transferred. On the sixteenth day after the transfer, the pregnancy diagnosis was made, and the recipients were grouped according to the gestational status in pregnant and non-pregnant mares.

\section{Statistical analysis}

The arcsine $(\sqrt{ } \mathrm{P} / 100)$ transformation was applied to the percentage data, and the results were expressed as mean (.) \pm standard error of the mean (SEM). Further, the assumptions of normality and homoscedasticity were verified, respectively, based on the Shapiro-Wilk and Lilliefors tests. Regarding the parametric and non-parametric variables, were applied, respectively, analysis of variance (ANOVA) followed by Tukey's test, and the Kruskal-Wallis test followed by Dunn's test. Pearson's correlation coefficient was used to evaluate the relationship between the parameters. The statistical program SPSS 16.0 (SPSS-22) ${ }^{8}$ was used to perform the over-mentioned analyses, and a $P$-value $<0.05$ was taken as significant.

\section{RESULTS}

The evaluation of the uterus and corpus luteum, as well as the serum progesterone levels from pregnant $(53.33 \%)$ and non-pregnant $(46.67 \%)$ mares are shown in Table 1. Progesterone concentration and corpus luteum vascular perfusion based on the 
objective and subjective evaluations were higher $(P<$ $0.05)$ in the pregnant mares than in the non-pregnant ones. There was no significant difference between the groups considering the uterine tonus evaluation $(P>0.05)$.

Table 2 shows the correlation coefficient between the evaluated parameters. There was a positive correlation $(P<0.05)$ between the objective and subjective evaluation methods of the corpus luteum vascular perfusion (Figure 1). Additionally, the progesterone concentration was positive and significantly correlated to the vascular perfusion of the corpus luteum and endometrium, considering both the objective and subjective methods $(P<0.05)$. There was a positive correlation between the diameter of the corpus luteum and its area $(P<0.05)$.

Table 1. Mean values (mean \pm standard deviation) of the uterus and corpus luteum ultrasonographic parameters, as well as the progesterone concentration from recipient mares stimulated at the embryo transfer timing.

\begin{tabular}{lcc}
\hline \multirow{2}{*}{ Parameter } & \multicolumn{2}{c}{ Mares } \\
\cline { 2 - 3 } & Pregnant & Non-pregnant \\
\hline Objective vascular perfusion in the endometrium $\left(\mathrm{mm}^{2}\right)$ & $357.56 \pm 103.93^{\mathrm{a}}$ & $181.37 \pm 54.60^{\mathrm{a}}$ \\
Subjective vascular perfusion in the endometrium $(1-4)$ & $1.87 \pm 0.39^{\mathrm{a}}$ & $2.14 \pm 0.24^{\mathrm{a}}$ \\
Uterine tonus (1- 4) & $2.75 \pm 0.36^{\mathrm{a}}$ & $2.57 \pm 0.40^{\mathrm{a}}$ \\
Objective vascular perfusion in the corpus luteum $\left(\mathrm{mm}^{2}\right)$ & $1216.97 \pm 74.45^{\mathrm{a}}$ & $661.81 \pm 117.11^{\mathrm{b}}$ \\
Subjective vascular perfusion in the corpus luteum $(\%)$ & $51.00 \pm 2.07^{\mathrm{a}}$ & $41.45 \pm 3.15^{\mathrm{b}}$ \\
Area of the corpus luteum $\left(\mathrm{mm}^{2}\right)$ & $7.66 \pm 0.36^{\mathrm{a}}$ & $7.41 \pm 0.91^{\mathrm{a}}$ \\
Diameter of the corpus luteum $(\mathrm{mm})$ & $31.53 \pm 1.84^{\mathrm{a}}$ & $30.68 \pm 1.82^{\mathrm{a}}$ \\
Progesterone concentration $(\mathrm{ng} / \mathrm{mL})$ & $10.64 \pm 1.13^{\mathrm{a}}$ & $7.19 \pm 3.49^{\mathrm{b}}$ \\
Ovulation (days) & $5.00 \pm 0.26^{\mathrm{a}}$ & $4.28 \pm 0.18^{\mathrm{a}}$ \\
\hline
\end{tabular}

Parameters with different letters in the same row are statistically significant $(P<0.05)$.

Table 2. Pearson's correlation coefficients (r) among ultrasonographic parameters of the uterus and corpus luteum, as well as progesterone concentration from recipient mares stimulated at embryo transfer timing.

\begin{tabular}{lc}
\hline Correlated Parameter & $\mathbf{r}$ \\
\hline Objective vascular perfusion in the corpus luteum $v s$ Subjective vascular perfusion in the corpus luteum & $0.66^{*}$ \\
Objective vascular perfusion in the corpus luteum $v$ S Progesterone concentration & $0.63^{*}$ \\
Subjective vascular perfusion in the corpus luteum $v s$ Progesterone concentration & $0.69^{*}$ \\
Objective vascular perfusion in the corpus luteum $v$ Corpus luteum diameter & -0.03 \\
Objective vascular perfusion in the corpus luteum $v s$ Corpus luteum area & -0.33 \\
Corpus luteum diameter $v s$ Corpus luteum area & $0.98^{*}$ \\
Progesterone concentration $v$ Corpus luteum diameter & -0.28 \\
Progesterone concentration $v s$ Corpus luteum area & -0.20 \\
Progesterone concentration $v$ Uterine tonus & 0.25 \\
$* P<0.05$. &
\end{tabular}

\section{DISCUSSION}

The hypothesis proposed in this study was that color Doppler ultrasound evaluation would allow identifying higher vascular perfusion of the corpus luteum in pregnant mares when compared to the non-pregnant ones. Furthermore, it was hypothesized that the objective and subjective methods for corpus luteum evaluation by using the color Doppler mode are correlated. The first hypothesis was confirmed once a higher number of colored pixels was identified in the ultrasound images from the corpus luteum of the pregnant mares. Likewise, there was a significant correlation between objective and subjective evaluation methods. These results highlight the importance of color Doppler evaluation as an efficient tool to select the best recipients for embryo transfer in horses. 
Considering that there was no difference on the ovulation day between pregnant and nonpregnant mares, it was also expected no differences regarding the progesterone concentration between the groups. However, mares that later became pregnant showed a higher concentration of progesterone as an outcome of the higher vascularization in the corpus luteum. It can be supported by both the correlation between the progesterone concentration and the corpus luteum vascular perfusion, as well as by the higher values of the vascular perfusion in pregnant mares. Furthermore, this result corroborates the hypothesis that the corpus luteum with a higher vascularization produces more progesterone $[11,13]$. From a histological point of view, this higher vascularization is a result of the contact between the luteal cell and the capillaries developed at the beginning of the corpus luteum formation, which is essential for its functionality and, consequently, to maintain the pregnancy $[5,7,10]$.

The significant correlations identified among the objective and subjective methods with the corpus luteum vascular perfusion, as well as with progesterone levels are supported by the previous reports $[4,15,21]$. These authors reported a significant relationship between the corpus luteum vascular perfusion, based on the subjective evaluation, and the progesterone concentration. Considering these authors and the results reported here, it is possible to validate the subjective analysis and recommend it to be applied for the selection of embryo recipient mares.

The absence of correlation among the area and the diameter of the corpus luteum with its vascular perfusion and also with the progesterone concentration was already reported $[2,4]$. The findings reported here allow us to state that the corpus luteum dimensions neither affect the progesterone production nor pregnancy. It is also possible to consider that the evaluation of the corpus luteum morphometric parameters alone does not provide any relevant information about its functional capacity, as reported by Veronesi et al. [22] and Lüttgenau et al. [15].

Although there was an expectation that uterine tonus and endometrial perfusion influence the pregnancy rate, these parameters did not differ between pregnant and non-pregnant mares. Furthermore, there was no correlation between uterine tonus and progesterone concentration. These findings do not support those reported by McCue et al. [16], Bollwein et al . [4] and Ginther et al. [11], who reported significant correlations among uterine tonus, progesterone concentration, and pregnancy rate. Considering that there is no agreement between the results reported by that authors and those found here, likely the uterine tonus is not a reliable parameter to predict the pregnancy rate. It is worthwhile to mention that the pregnancy rates obtained here were similar to those reported in the literature $[23,24]$ and supports the efficacy of the equine embryo transfer methodology used in this study.

\section{CONCLUSIONS}

Based on the results, it has been concluded that the color Doppler ultrasound evaluation is an accurate tool to determine the corpus luteum vascularization, whether considering the objective or subjective methods. Additionally, the selection of mares with a higher corpus luteum vascular perfusion at the embryo transfer timing is the most efficacious parameter to predict the corpus luteum function and the ability of the mare to maintain pregnancy.

\section{MANUFACTURERS}

${ }^{1}$ Dsm Produtos Nutricionais Brasil S.A. São Gonçalo do Amarante, CE, Brazil.

${ }^{2}$ Zoetis Indústria de Produtos Veterinários Ltda. Campinas, SP, Brazil. ${ }^{3}$ Ouro Fino Saúde Animal Ltda. Cravinhos, SP, Brazil.

${ }^{4}$ SonoScape Medical Corp. Shanghai, China.

${ }^{5}$ Adobe Inc. Boston, MA, U.S.A.

${ }^{6}$ Greiner Bio-one Brasil Produtos Médicos Hospitalares Ltda. Americana, SP, Brazil.

${ }^{7}$ Siemens Healthineers AG. Los Angeles, CA, U.S.A.

${ }^{8}$ International Business Machines Corporation. Chicago, IL, USA.

Funding. The present work was carried out with support from the Coordenação de Aperfeiçoamento de Pessoal de Nível Superior - Brasil (CAPES) - Finance Code 001.

Ethical approval. This study was approved by the animal ethics committee of the Federal Rural University of Pernambuco, CEUA-UFRPE (protocol number 011/2013).

Declaration of interest. The authors report no conflicts of interest. The authors alone are responsible for the content and writing of the paper. 


\section{REFERENCES}

1 Acosta T.J. \& Miyamoto A. 2004. Vascular control of ovarian function: Ovulation, corpus luteum formation and regression. Animal Reproduction Science. 82-83: 127-140.

2 Arruda R.P., Visintin J.A. Fleury J.J., Garcia A.R., Madureira E.H., Celeghini E.C.C. \& Neves Neto J.R. 2001. Existem relações entre tamanho e morfoecogenicidade do corpo lúteo detectados pelo ultra-som e os teores de progesterona plasmática em receptoras de embriões eqüinos? Brazilian Journal of Veterinary Research and Animal Science. 38(5): 233-239.

3 Azevedo M.V., Souza N.M., Ferreira-Silva J.C., Batista I.O., Moura M.T., Oliveira M.A.L., Alvarenga M.A. \& Lima P.F. 2015. Induction of multiple ovulations in mares using low doses of GnRH agonist Deslorelin Acetate at 48 hours after luteolysis. Pferdeheilkunde. 31(2): 160-164.

4 Bollwein H., Mayer R., Weber F. \& Stolla R. 2002. Luteal blood flow during the estrous cycle in mares. Theriogenology. 57(8): 2043-2051.

5 Carnevale E.M., Ramirez R.J., Squires E.L., Alvarenga M.A., Vanderwall D.K. \& McCue P.M. 2000. Factors affecting pregnancy rates and early embryonic death after equine embryo transfer. Theriogenology. 54(6): 965-979.

6 Curran S. \& Ginther O.J. 1995. M-mode ultrasonic assessment of equine fetal heart rate. Theriogenology. 44(5): 609-617.

7 Dharmarajan A.M., Bruce N.W. \& Meyer G.T. 1985. Quantitative ultrastructural characteristics relating to transport between luteal cell cytoplasm and blood in the corpus luteum of the pregnant rat. American Journal of Anatomy. 172(1): 87-99.

8 Ferreira J.C., Ignácio F.S. \& Meira C. 2011. Doppler ultrasonography principles and methods of evaluation of the reproductive tract in mares. Acta Scientiae Veterinariae. 39(Supl 1): s105-s111.

9 Ferreira-Silva J.C., Sales F.A.B.M., Nascimento P.S., Moura M.T., Freitas-Neto L.M., Rocha J.M., Ferreira H.N. \& Oliveira M.A.L. 2019. Evaluation of embryo collection and transfer days on pregnancy rate of mangalarga marchador mares during the breeding season. Revista Colombiana de Ciências Pecuárias. 32(3): 214-220.

10 Ferreira J.C., Novaes Filho L.F., Boakari Y.L., Canesin H.S., Thompson D.L., Lima F.S. \& Meira C. 2018. Hemodynamics of the corpus luteum in mares during experimentally impaired luteogenesis and partial luteolysis. Theriogenology. 107: 78-84.

11 Ginther O.J., Gastal E.L., Gastal M.O., Utt M.D. \& Beg M.A. 2007. Luteal blood flow and progesterone production in mares. Animal Reproduction Science. 99(1-2): 213-220.

12 Ginther O.J. \& Utt M.D. 2004. Doppler ultrasound in equine reproduction: Principles, techniques, and potential. Journal of Equine Veterinary Science. 24(12): 516-526.

13 Ishak G.M., Bashir S.T., Gastal M.O. \& Gastal E.L. 2017. Pre-ovulatory follicle affects corpus luteum diameter, blood flow, and progesterone production in mares. Animal Reproduction Science. 187: 1-12.

14 Iuliano M.F., Squires E.L. \& Cook V.M. 1985. Effect of age of equine embryos and method of transfer on pregnancy rate. Journal of Animal Science. 60(1): 258-263.

15 Lüttgenau J., Ulbrich S.E., Beindorff N., Honnens A., Herzog K. \& Bollwein H. 2011. Plasma progesterone concentrations in the mid-luteal phase are dependent on luteal size, but independent of luteal blood flow and gene expression in lactating dairy cows. Animal Reproduction Science. 125(1-4): 20-29.

16 McCue P.M., Vanderwall D.K., Keith S.L. \& Squires E.L. 1999. Equine embryo transfer: Influence of endogenous progesterone concentration in recipients on pregnancy outcome. Theriogenology. 51(1):267.

17 Mortensen C.J., Choi Y.H., Hinrichs K., Ing N.H., Kraemer D.C., Vogelsang S.G. \& Vogelsang M.M. 2009. Embryo recovery from exercised mares. Animal Reproduction Science. 110(3-4): 237-244.

18 Nagao J.F., Neves Neto J.R., Papa F.O., Alvarenga M.A., Freitas-Dell'Aqua C.P. \& Dell'Aqua J.A. 2012. Induction of double ovulation in mares using deslorelin acetate. Animal Reproduction Science. 136(1-2): 69-73.

19 Niswender G.D., Juengel J.L., Silva P.J., Rollyson M.K. \& McIntush E.W. 2000. Mechanisms controlling the function and life span of the corpus luteum. Physiological Reviews. 80(1): 1-29.

20 Oliveira Neto I.V., Canisso I.F., Segabinazzi L.G., Dell'Aqua C.P.F., Alvarenga M.A., Papa F.O. \& Dell'Aqua J.A. 2018. Synchronization of cyclic and acyclic embryo recipient mares with donor mares. Animal Reproduction Science. 190: 1-9. 
M.V. Azevedo, N.M. Souza, F.A.B.M. Sales, et al. 2021. Evaluation of Corpus Luteum Vascularization in Recipient Mares by Using Color Doppler Ultrasound. Acta Scientiae Veterinariae. 49: 1792.

21 Romano R.M., Ferreira J.C., Canesin H.S., Boakari Y.L., Ignácio F.S., Novaes Filho L.F., Thompson D.L. \& Meira C. 2015. Characterization of Luteal Blood Flow and Secretion of Progesterone in Mares Treated with Human Chorionic Gonadotropin for Ovulation Induction or During Early Diestrus. Journal of Equine Veterinary Science. 35(7): 591-597.

22 Veronesi M.C., Battocchio M., Marinelli L., Faustini M., Kindahl H. \& Cairoli F. 2002. Correlations among body temperature, plasma progesterone, cortisol and prostaglandin F2 $\alpha$ of the periparturient bitch. Journal of Veterinary Medicine Series A: Physiology Pathology Clinical Medicine. 49(5): 264-268.

23 Wilsher S. \& Allen W.R. 2009. Uterine influences on embryogenesis and early placentation in the horse revealed by transfer of day 10 embryos to day 3 recipient mares. Reproduction. 137(3): 583-593.

24 Wilsher S., Clutton-Brock A. \& Allen W.R. 2010. Successful transfer of day 10 horse embryos: Influence of donorrecipient asynchrony on embryo development. Reproduction. 139: 575-585. 